\title{
IMPORTANCE OF SOFT SKILLS AND COMMUNICATION SKILLS IN TOURISM: VIEWPOINT FROM TOURISTS AND FUTURE TOURISM EMPLOYEES
}

\author{
Ana Čuić Tanković \\ Jelena Kapeš \\ Valentina Kraljić
}

https://doi.org//10.20867/tosee.06.12

\begin{abstract}
Purpose - Besides possessing professional knowledge, tourism service providers need to have expressed communication skills and soft skills in order to offer a better tourism service. In this paper, the tourism employees' set of soft and communication skills is analysed and compared from two different points of view: tourists on the one hand and future tourism professionals, i.e., tourism students, on the other. Therefore, the main purpose of this study is to analyse the importance and differences in the perception of soft skills and communication skills in the tourism and hospitality sector from these two standpoints.

Methodology - Two structured questionnaires were used to collect primary data: the first questionnaire aimed at examining the tourists' attitudes regarding the importance of soft and communication skills $(\mathrm{N}=431)$, and the second one, at analysing the importance of soft and communication skills from the perspective of future tourism professionals $(\mathrm{N}=404)$. The research results are presented using descriptive statistics, the t-test, and the Mann-Whitney U test.

Findings - The results indicate that both groups are aware of the importance of communication and soft skills. The statistically significant differences between the tourist sample and the future tourism professional sample were found for all items of the Soft skills factor, with the exception of the items Demonstrating respect, Integrity, and Responsibility. Both samples show similarities with regard to all kinds of Communication skills. Statistically significant differences in the perception of all five Communication skills items from tourists' and future tourism professionals' perspectives were found.

Contribution - The paper contributes to the theory by systematizing and analysing the literature and conceptualizing the soft skills and communication skills up to date. Its empirical contribution derives from the examination of data related to the tourist sample and the future tourism employee sample. This different point of view contributes to filling the research gap and opens new future research directions. By examining the most important soft skills and communication skills from these two perspectives, this study provides a practical implication for tourism educators and hospitality managers, revealing the communication skills and soft skills that require further development.
\end{abstract}

Keywords: communication skills; soft skills; tourism employees; tourists.

\section{INTRODUCTION}

Tourism is an industry well known for being labour intensive, communication intensive, and intercultural (Summak 2014). It does not sell conventional products, but rather services that come in the form of experiences. Hence, the job of tourism employees 
ToSEE - Tourism in Southern and Eastern Europe, Vol. 6, pp. 167-185, 2021.

A. Čuić Tanković, J. Kapeš, V. Kraljić: IMPORTANCE OF SOFT SKILLS AND COMMUNICATION ...

gradually has transformed from "service providers" to "experience providers" (Bharwani and Jauhari 2013), requiring the possession of some new skills. To work in the tourism industry, a balance of two types of skills is required: hard skills and soft skills. Hard skills refer to technical or cognitive competences that can be taught, such as working with equipment or software (Laker and Powell 2011; Sisson and Adams 2013). On the other hand, soft skills imply personal characteristics needed to apply technical knowledge, such as interpersonal, people, or behavioural competences (Weber et al. 2013). Soft skills encompass the skills of dealing with others and self-managing skills (Sitompul, Dalimounthe, and Syahputra 2018). Sisson and Adams (2013) warn that although technical skills are important and must be taught in schools or universities, they should not take precedence over soft skills.

In the tourism and travel industry, soft skills are particularly important. Youssef (2017) emphasizes two main reasons why they are a crucial requirement to working in the tourism industry. Firstly, tourism is a people-based industry that encompasses many different service providers whose soft skills enable them to work together and serve the customer properly. Furthermore, tourism is a leisure activity and the employees' soft skills will contribute to tourist happiness more than a destination itself. As Raybould and Wilkins (2006) state, in the past few decades the required skills in hospitality have largely changed, decreasing the importance of operational and technical skills, while increasing the need for soft skills.

One of the most important soft skills needed in the tourism workplace are communication skills (Wesley, Jacskon, and Lee 2017; Jiang and Alexakis 2017; Zehrer and Mössenlechner 2009). Today's business environment requires employees to be able to communicate in various settings, formally and informally, face-to-face and virtually, nationally and internationally, and with multi-cultural and multi-generational audiences (Jackson 2014). In tourism and hospitality, these communication skills go far beyond the conveying of a message. They are associated with written or oral verbalization, listening, and non-verbal cues that form part of the tourist experience and build relationships. Only through proper communication can tourism marketers provide some tangible cues about intangible tourist experiences (Youssef 2017).

Many researchers have stressed the importance of communication skills development for graduate students (Conrad and Newberry 2012; Lim et al. 2016; Plant and Slippers 2015; Robles 2012; Wang et al. 2009; Zehrer and Mössenlechner 2009). Better social and communication skills are related to better job performance and employability, and individuals with a higher level of communication skills tend to be chosen as leaders (Weber et al. 2009; Succi and Canovi 2019). The importance and ubiquity of soft skills, and communication skills in particular, have been widely recognized so it has become a prominent topic of research, especially in terms of the soft skills of students required for their future workplace. Despite the indisputable relevance of communication skills (Zehrer and Mössenlechner 2009; Robles 2012; Conrad and Newberry 2012; Stevens 2005), existing studies show that the preparedness of future tourism employees in terms of these skills is insufficient (Lolli 2013; Stevens 2005). According to Singh and Jaykumar (2019), there is a serious gap between the demand for qualified entry-level employees and the available supply in the service sector. 
ToSEE - Tourism in Southern and Eastern Europe, Vol. 6, pp. 167-185, 2021.

A. Čuić Tanković, J. Kapeš, V. Kraljić: IMPORTANCE OF SOFT SKILLS AND COMMUNICATION ...

While the growing interest in exploring the perspectives of future tourism employees and the expectations of the tourism industry regarding soft skills and communication skills is evident, only a few studies have focused on the importance of tourism employee skills from the perspective of tourists. Nonetheless, researchers generally agree that employee behaviour is a vital factor in shaping customer's perceptions of the service (Wall and Berry 2007, Baker et al. 2013; Wu et al. 2015). Moreover, according to Barnes et al. (2020), the satisfaction of tourists depends heavily on their personal interaction with tourism employees who need to possess various soft skills.

However, the changing nature of the tourism and hospitality environment requires continuous research of skills to regularly update the knowledge (Raybould and Wilkins. 2006). Besides the constant changes on the tourism demand side, it should be noted that there is a new generational cohort entering the tourism and hospitality workforce whose characteristics and work attitudes have yet to be explored (Goh and Lee 2018). Therefore, further research on soft skills and communication skills is needed (Wesley, Jacskon, and Lee 2017). However, studies to date have been investigating soft skills sorely on the sample of consumers (Alhelalat, Habiballah, and Twaissi 2017; Wu et al. 2015) or the sample of students as future tourism employees (Wesley, Jackson, and Lee 2017; Succi and Canovi 2019; Singh and Jaykumar 2019). Similarly, communication skills have been discussed considering the sample of service customers (Mustelier-Puig, Anjum, and Ming 2019; Alshatnawi 2013) or students as future tourism employees (Lolli 2013; Özdipçiner, Ceylan, and Aktaş 2017; Loreto 2020). No study so far has presented the comparison of these two fundamental stakeholders in tourism regarding these specific skills, which would fill the gap of better understanding the differences in their perceptions. Therefore, this research attempts to fulfill this gap and enhance the understanding of soft skills and communication skills in tourism from the perspective of both future tourism employees and tourists.

Additionally, the paper aims to present a systematization of the key soft skills and communication skills for both future tourism employees and tourists.

The paper is structured into five main parts. After the introduction, the literature review on soft skills and communication skills is presented in the second part. The third part details the methodology and is followed by research results. Finally, the fifth part brings concluding remarks with implications and suggestions for future research

\section{LITERATURE REVIEW}

\subsection{Soft skills in tourism encounter}

Soft skills are personal attributes that improve the interaction of individuals and their ability to perform a particular job (Hendarman and Tjakraatmadja 2012). They can be defined as a combination of personal qualities, abilities, attitudes, and habits of an individual (Pandey and Pandey 2015), which allows them to deal effectively with the challenges of professional and everyday life (Hurrell 2016). Muzio and Fisher (2009) explained that soft skills allow an individual to better understand their own actions and 
ToSEE - Tourism in Southern and Eastern Europe, Vol. 6, pp. 167-185, 2021.

A. Čuić Tanković, J. Kapeš, V. Kraljić: IMPORTANCE OF SOFT SKILLS AND COMMUNICATION ...

how to work with others, while Ranade et al. (2010) identified soft skills as behaviour that makes employees more effective in what they do and directs them toward goals.

Soft skills cover a wide range of different skills that have a significant impact on the successful communication of tourism employees. By synthesizing the available literature and research by different authors (Tesone and Ricci 2005, Cheung, Law and He 2010. Robles 2012, Suh, West and Shin 2012, Testa and Sipe 2012, Wang and Tsai 2014, Succi and Canovi 2019, Weber, Lee, and Crawford 2019), these skills can be classified into several groups. The first group refers to communication skills that are most often associated with listening, presenting, and verbal and nonverbal communication skills. The second group comprises interpersonal skills which are related to the skills of developing good relationships and cooperation, giving and receiving effective feedback, and motivational skills. The next group refers to emotional intelligence which consists of interpersonal intelligence that includes skills such as self-control, self-awareness, and self-motivation. The fourth group, intrapersonal intelligence, includes skills such as empathy and assertiveness, and change and stress management skills. The last group refers to professionalism which is most often defined through the possession of work ethic and knowledge of business etiquette, the ability to constructively resolve conflicts, and effective time management.

Unlike hard skills that refer to an individual's ability to perform a particular type of task, soft skills are widely applicable (Hendarman and Tjakraatmadja 2012) and can refer to all competencies that are not directly related to a particular task, but are vital because they primarily contribute to human relationships (Dogara et al. 2020). Also, hard skills usually require the acquisition of knowledge (Ciappei and Cinque 2014) and are relatively easy to learn and measure, while soft skills are difficult to measure or prove because they arise from the psychological personality, preferences, and experiences of individuals (Balcar 2016). Historically, hard skills were, for a long time, the only skills needed for employment, but in today's environment, hard skills alone are no longer sufficient (Robles 2012) and the prevailing view is that without soft skills, such as interpersonal and relationship building skills, individuals cannot communicate and collaborate effectively (Wesley, Jackson, and Lee 2017).

This is particularly important in tourism and hospitality where interaction between tourists and tourism employees has become an integral part of the tourism product (Burns 1997), and very often it is an important factor in tourists' perceptions of overall service quality (Nickson, Warhurst, and Dutton 2005). Despite the high level of technological development and the availability of technology in the workplace, tourism and hospitality companies still depend heavily on labour-intensive inputs of their workforce (Baum et al. 2016). Thus, the tourism product, which is essentially a service and tourist experience, largely depends on the emotional intelligence and other characteristics, habits, and abilities of tourism employees.

Services in tourism and hospitality can be viewed from a technical aspect, such as waiting time, cleanliness, or organization, and from the aspect of interpersonal relationships, which includes the relationship of employees to tourists. Testa and Sipe (2012) believe that a quality tourist service must include both aspects to meet the needs of tourists; while the technical aspect is expected, the interpersonal aspect gives additional value and tone 
ToSEE - Tourism in Southern and Eastern Europe, Vol. 6, pp. 167-185, 2021.

A. Čuić Tanković, J. Kapeš, V. Kraljić: IMPORTANCE OF SOFT SKILLS AND COMMUNICATION ...

to each tourist experience and often exceeds their expectations. Therefore, tourism employees are often expected to recognize and make decisions on the spot about what they think will please individuals, encourage positive emotions in them, and achieve greater emotional value (Nickson, Warhurst, and Dutton 2005). Despite these expectations and remarkable impact on tourist satisfaction, soft skills in tourism and hospitality are very often underestimated, sometimes classified as low skills, or interpreted as a part of the natural order of things (Burns 1997).

Employers perspective of soft skills (Gruzdev et al. 2018; Zehrer and Mössenlechner 2009; Coffelt, Grauman, and Smith 2019) recently has been extensively researched.

Although graduates nowadays are technically savvy and possess many functional skills, they lack soft skills such as customer service and interpersonal skills (Singh and Jaykumar 2019). On the other hand, these interpersonal skills are highly valued by tourists in shaping their experience (Wu et al. 2015; Barnes 2020). Hence, the soft skills of young tourism professionals entering the labour market do not fit the criteria of the tourism workplace (Singh and Jaykumar 2019; Gruzdev et al. 2018).

Given that these skills are often underestimated by the younger generation (Schroth 2019; Bencsik, Horváth-Csikós, and Juhász 2016.) and that tourists highly value them during the tourism encounter, the first hypothesis is defined:

H1: There is a statistically significant difference between tourists and future tourism employees in the perception of soft skills.

\subsection{Communication skills in tourism encounter}

Communication skills have been recognized as one of the most important soft skills within and outside of the tourism context (Wesley, Jackson, and Lee 2017; Jiang and Alexakis 2017; Succi and Canovi 2019; Robles 2012). These skills refer to the ability to share ideas, feelings, opinions, and information between two or more parties in a way that a common understanding of the message among all parties is ensured (Youssef 2017). As mentioned earlier, tourism is a labour-intense industry that does not sell tangible goods, but services that appear in the form of experiences. Therefore, communication is vital in tourism since the personal encounter of tourists and employees makes up a great part of the tourism experience. According to Nikolich and Sparks (1995) there are two basic areas of communication that influence satisfaction in the service encounter: (1) the ability of service providers to clearly communicate a message to the customer, and (2) the utilization of communication strategies to develop a relationship with customers.

Effective communication with customers requires the possession of various skills that enable communication in multiple settings. The most common classification distinguishes between verbal and non-verbal communication skills.

The fundamental communication skills that are most commonly addressed by researchers are oral and written communication skills (Jones 2011; Kleckner and Marshall 2014; MacDermott and Ortiz 2017; Morgan 1997; Lolli 2013; Ulinski and O'callaghan 2002). 
ToSEE - Tourism in Southern and Eastern Europe, Vol. 6, pp. 167-185, 2021.

A. Čuić Tanković, J. Kapeš, V. Kraljić: IMPORTANCE OF SOFT SKILLS AND COMMUNICATION ...

Oral communication skills include a range of activities such as presenting, public speaking, giving and receiving feedback, negotiating, but also adapting the communication to the audience and keeping their attention (Gray and Murray 2011; Jackson 2014; Morgan 1997; Ulinski and O'callaghan 2002). These skills are emphasized by many authors as the most needed in today's workplace (Coffelt, Baker, and Corey 2016). However, according to several studies, the level of oral communication skills of young employees appears to be insufficient (Stevens 2005; Coffelt, Baker, and Corey 2016) and the need for their future development is highly recommended.

Notwithstanding the importance of speaking skills, the skill of listening should not be disregarded. In fact, it is considered to be the most important and most common communication activity in the business environment (Keyton et al. 2013). In the tourism industry, listening is of great importance regarding the two previously mentioned areas of communication that influence service satisfaction (Nikolich and Sparsk 1995). The employees who listen to their colleagues and customers resolve problems more effectively and build strong relationship with their customers more easily (Brownell 2009; Lolli 2013). However, to listen effectively, a set of skills has to be acquired. The message has to be heard, understood, remembered, interpreted, evaluated, and responded to (Brownell 2016).

Writing communication skills, one of the most common skills to appear in the literature, refer to abilities such as writing documents and memos in a clear and concise manner, following a logical order and ensuring grammatical and spelling accuracy, as well as adjusting the style and message to various document forms and audiences (Jones 2011; Morgan 1997). It should be noted that due to technological advancements, written communication has largely changed. Nonetheless, Coffelt, Baker and Corey (2016) state that traditional writing skills are still highly valued by employers. Moreover, some studies show that young employees lack certain writing communication skills (Jones 2011).

As observed, information technology has greatly affected the tourism industry, and the two have become inseparable. This has resulted in the need for new digital competences and skills that have become crucial to working in the information-intensive tourism industry (Carlisle, Ivanov and Dijkmans 2021). However, these skills go far beyond the conventional writing skills or the ability to use software (Eshet-Alkalai,2004). They include a range of skills such as creating, displaying and sharing digital information, communication through e-mail and social media, understanding the netiquette, and being aware of the consequences of information sharing (Siddiq, Scherer, and Tondeur 2016; Jones 2011; Ferrari 2013). Given the dynamism of technological changes, Carlisle, Ivanov and Dijkmans (2021) state that the future will bring only more diversity in systems and software in tourism and, thereby, more new digital communication skills will be required.

In addition to using written or spoken words, communication also occurs non-verbally. Moreover, according to previous research, the verbal part accounts only for $7 \%$ of the message, while $38 \%$ refers to the vocal part and 55\%, to non-verbal language (Mandal 2014). Knapp, Hall and Horgan (2014) have classified non-verbal communication into three main groups: (1) communication environment, such as interior, exterior, lightning or temperature, (2) physical characteristics of the communicator, such as appearance, posture, or apparel, and (3) body movements and facial expressions. Given the specific context of 
ToSEE - Tourism in Southern and Eastern Europe, Vol. 6, pp. 167-185, 2021.

A. Čuić Tanković, J. Kapeš, V. Kraljić: IMPORTANCE OF SOFT SKILLS AND COMMUNICATION ...

tourism services, although understudied, non-verbal communication is extremely important since it largely influences the perception of service (Islam and Kirilova 2020).

As observed, communication skills appear to be a crucial factor in providing excellent tourist service although the empirical research on the tourist perception of communication skills is very limited. Both verbal and non-verbal communication is of utmost importance for any service encounter because it directly influences customer satisfaction (Mustelier-Puig and Xu Ming 2019). On the other hand, multiple studies have confirmed that the communication skills of new employees do not fully match the tourism job requirements (Lolli 2013; Stevens 2005; Paranto and Kelkar 2000). Moreover, some recent research on new generations of graduates has revealed that, due to the prevalence of virtual communication, they have missed out to learn some basics of interpersonal communication, especially regarding oral and written communication skills (Gaidhani, Arora, and Sharma 2019; Bencsik, Horváth-Csikós, and Juhász 2016; Schroth 2019). Accordingly, new generations of entry-level graduates neither possess the same communication skills nor find them equally important as their predecessors (Pečiuliauskienè 2018; Gaidhani, Atrora, and Sharma 2019; Turner 2015). Due to these differences, discrepancies are expected between the employee perspective and the tourist perspective. Accordingly, the second hypothesis is defined:

$\mathrm{H} 2$ : There is a statistically significant difference between tourists and future tourism employees in the perception of communication skills.

\section{METODOLOGY}

Two structured questionnaires were used to collect primary data: the first aimed at examining tourist attitudes regarding the importance of soft skills and communication skills, and the second analysed the importance of soft skills and communication skills from the perspective of future tourism professionals. Empirical research using the survey method was conducted from February to May 2020 on a sample of Croatian tourists, and from January 2019 to January 2020 on a sample of future tourism employees. A structured questionnaire was used as a measuring instrument in both surveys, distributed online by email and social media to a convenience sample. Tourism and hospitality students in Croatia were the target population for the future tourism employee sample. The questionnaire was administered to all full-time students at the Faculty of Tourism during their class periods. A total of 404 questionnaires were collected from future tourism professionals and 431 , from tourists. In total, 835 correctly completed questionnaires were collected and used in further analysis.

The measuring instrument's design was based on the relevant literature and scientific research in this field, and the questions were adopted for this study. The questionnaire for tourists contained a screening question, asking whether the respondents had used a tourism service in the last 12 months. Both questionnaires had the same previously validated scale, which measured the perceived importance of communication skills, divided into five dimensions, representing the five core types of communication skills: written communication (Jones 2011), oral communication (Jackson 2014), listening skills (Brownells HURIER model), digital skills (Siddiq, Scherer, and Tondeur 2016), 
ToSEE - Tourism in Southern and Eastern Europe, Vol. 6, pp. 167-185, 2021.

A. Čuić Tanković, J. Kapeš, V. Kraljić: IMPORTANCE OF SOFT SKILLS AND COMMUNICATION ...

and non-verbal communication skills (Limbu et al. 2016). The set of items regarding soft skills is adopted from Conrad and Newberry (2012).

Participants were asked to indicate their perceived importance of all items in the tourism workplace using a 5-point Likert scale (1 - extremely unimportant, 5 - extremely important). Socio-demographic data was collected at the end of both questionnaires.

\section{DATA ANALYSIS}

The collected data were analysed with IBM Statistics SPSS. The independent t-test was performed to compare the differences between future tourism professionals and tourists in their perception of communication skills and soft skills.

\subsection{Profile of future tourism professionals}

The demographic data collected on the students included gender, age, year of study, and study program (Table 1). Of the respondents, the majority, 78 percent, were female, and 98 percent were from 19 to 25 years old. Regarding the year of study, 27 percent of the respondents were $1^{\text {st }}$ and $2^{\text {nd }}$ undergraduate students, and 20 percent of respondents were graduate students. The majority of the respondents (45 percent) were enrolled in the study program Tourism Management, followed by Hospitality Management (26 percent) and Sustainable Tourism Development (25 percent).

Table 1: Demographic data of future tourism professional

\begin{tabular}{llrr}
\hline \multirow{2}{*}{ Features } & Frequency & Percentage \\
\hline \multirow{2}{*}{ Gender } & Female & 315 & 78 \\
& Male & 89 & 22 \\
\hline \multirow{4}{*}{ Age } & 18 or less & 4 & 1 \\
& $19-21$ & 228 & 56 \\
& $22-25$ & 168 & 42 \\
& $26-30$ & 4 & 1 \\
\hline \multirow{4}{*}{ Year of } & $1^{\text {st }}$ year of undergraduate study & 110 & 27 \\
study & $2^{\text {nd }}$ year of undergraduate study & 110 & 27 \\
& $3^{\text {rd }}$ year of undergraduate study & 22 & 5 \\
& $4^{\text {th }}$ year of undergraduate study & 82 & 20 \\
\multirow{2}{*}{ Study } & $1^{\text {st }}$ year of graduate study & 80 & 20 \\
program & Tourism Management & 182 & 45 \\
& Hospitality Management & 104 & 26 \\
& Tourism Marketing & 15 & 4 \\
& Sustainable Tourism Development & 103 & 25 \\
\hline
\end{tabular}

Based on the question about the work experience of students, it was determined that the respondents had acquired an average of 17 months of work experience in tourism, of which the largest part in two areas - Food and Beverage (53 percent) and Reception (23 percent). Additional areas included Housekeeping (5 percent), Animation (5 percent), 
ToSEE - Tourism in Southern and Eastern Europe, Vol. 6, pp. 167-185, 2021.

A. Čuić Tanković, J. Kapeš, V. Kraljić: IMPORTANCE OF SOFT SKILLS AND COMMUNICATION ...

Travel agencies ( 4 percent), Tourist Board ( 2 percent), while the smallest share of respondents, 1 percent of the total number of respondents, gained work experience through Sales, Tourist guidance, work at the Info desk, or in the Wellness Department.

In addition to previous work experience, respondents were asked to identify a tourism area in which they would like to work upon completing their college education. The results are as follows: Accommodation (26 percent), Local / regional / national tourism organizations (20 percent), Travel agencies / Tour operators (19 percent), Food and Beverage (11 percent), Recreation and Animation (7 percent), Culture (4 percent), Education and Science (4 percent,) Transport (>1 percent). In addition to these eight listed areas, respondents were also given the option to state any other area they would like to work in and 8 percent of the respondents chose areas such as marketing, sustainable development, human resources, and others.

\subsection{Tourist profile}

The demographic data collected on the tourists included gender, age, education, employment, and marital status (Table 2). Of the respondents, the majority are female ( 83 percent), from 18 to 35 years of age (60 percent). Within the sample, 41 percent of the respondents have a graduate degree and 27 percent, an undergraduate degree. The majority of the respondents (57 percent) are employed, and 11 percent of respondents are unemployed. Regarding marital status, the majority of the respondents (53 percent) are unmarried, followed by married (33 percent), in an extramarital union ( 7 percent), divorced ( 5 percent), and widow/widower ( 2 percent).

Table 2: Tourists' demographic data

\begin{tabular}{llrr}
\hline \multirow{2}{*}{ Fender } & Frequency & Percentage \\
\hline \multirow{4}{*}{ Age } & Male & 74 & 17 \\
& Female & 357 & 83 \\
\hline & $16-25$ & 135 & 31 \\
& $26-35$ & 125 & 29 \\
& $36-45$ & 96 & 22 \\
& $46-55$ & 54 & 13 \\
& $56-65$ & 20 & 5 \\
\multirow{5}{*}{ Education } & 66 and above & 1 & 0 \\
& Elementary school & 2 & 0 \\
& High-school degree & 97 & 23 \\
& Undergraduate study & 117 & 27 \\
& Graduate study & 177 & 41 \\
& Postgraduate study / scientific master's & 38 & 9 \\
\hline
\end{tabular}


ToSEE - Tourism in Southern and Eastern Europe, Vol. 6, pp. 167-185, 2021. A. Čuić Tanković, J. Kapeš, V. Kraljić: IMPORTANCE OF SOFT SKILLS AND COMMUNICATION ...

Tables 2 (continued)

\begin{tabular}{llrr}
\hline \multicolumn{1}{c}{ Features } & Frequency & Percentage \\
\hline \multirow{5}{*}{ Employment } & 245 & 57 \\
& Employed & 48 & 11 \\
& Unemployed & 126 & 29 \\
& Student & 7 & 2 \\
& Retired & 5 & 1 \\
\hline \multirow{5}{*}{ Marital status } & Other & 143 & 33 \\
& Married & 228 & 53 \\
& Unmarried & 21 & 5 \\
& Divorced & 32 & 7 \\
& Extramarital union & 7 & 2 \\
\cline { 2 - 3 }
\end{tabular}

Since the questionnaire had the screening question, all respondents included in the sample have used some tourist service within the last 12 months. Within this sample, the majority of the respondents used hotel services (56 percent) and transport services ( 55 percent), followed by travel agency services (46 percent) and food services (46 percent). Fewer respondents used accommodation services (39 percent) and cultural services ( 28 percent), while the least number of respondents used recreation/sports services (17 percent).

By observing the demographic characteristics of these two independent samples, a chisquare test is performed to examine their independence. Taken into account that one sample is composed of future tourism employees, i.e. students who are younger and have yet to reach their desired level of education, the two samples were analysed for gender characteristics. It denotes a non-significant degree of differences between the samples $\left(\chi^{2}\right.$ $=3,123, \mathrm{p}<0.05)$. Therefore, the two samples have no differences in demographics, and further data analysis can proceed.

\subsection{Skills importance and differences}

The mean ranking of items for the future tourism professional sample, the tourist sample, and in total is shown below, as well as the results of the differences between the perception of importance of Communication skills and Soft skills for the two samples (Table 3). T-test for independent samples was applied to assess the significant difference between future tourism professionals' and tourists' perception of the importance of communication skills and soft skills (Table 3).

Scale reliability was measured with Cronbach's Alpha, which for both samples is 0.707 for Communication skills and 0.922 for Soft skills. Both reliability coefficients are higher than 0.70 , which is considered acceptable.

For future tourism professionals, Non-verbal skills (4.70 \pm 0.44$)$ and Oral communication skills $(4.60 \pm 0.48)$ are the most important variables of the Communication skills factor, while the items Kindness $(4.82 \pm 0.48)$ and Responsibility $(4.82 \pm 0.52)$ have the highest mean in the Soft skills factor. Tourists, on the other hand, rated Oral communication 
ToSEE - Tourism in Southern and Eastern Europe, Vol. 6, pp. 167-185, 2021.

A. Čuić Tanković, J. Kapeš, V. Kraljić: IMPORTANCE OF SOFT SKILLS AND COMMUNICATION ...

skills $(4.62 \pm 0.56)$ as the most important communication item, followed by Listening communication skills (4.54 \pm 0.63$)$. Among the soft skills items, Responsibility has the highest mean (4.79 \pm 0.51 ), along with Demonstrating respect (4.75 \pm 0.55$)$. Summarizing the results from both samples, the most prominent skills among Communication skills are Oral communication skills $(4.61 \pm 0.59)$ and Non-verbal communication skills (4.37 \pm 0.8$)$. For both samples $(\mathrm{N}=835)$, Oral communication skills $(4.61 \pm 0.54)$ is the most important item of the Communication skills factor, while the item Responsibility $(4.81 \pm 0.51)$ has the highest mean in the Soft skills factor.

Table 3: Mean ranking of communication skills and soft skills

\begin{tabular}{|c|c|c|c|c|c|c|c|}
\hline \multirow{2}{*}{ Items } & \multicolumn{2}{|c|}{$\begin{array}{l}\text { Future tourism } \\
\text { professionals }\end{array}$} & \multicolumn{2}{|c|}{ Tourists } & \multicolumn{2}{|c|}{ Total } & \multirow[t]{2}{*}{$\mathrm{F}$} \\
\hline & Mean & SD & Mean & $\mathrm{SD}$ & Mean & $\mathrm{SD}$ & \\
\hline \multicolumn{8}{|l|}{ Communication skills } \\
\hline \multicolumn{8}{|l|}{ Cronbach's Alpha $=0.707$} \\
\hline $\begin{array}{l}\text { Written communication } \\
\text { skills }\end{array}$ & 4.31 & 0.52 & 4.19 & 0.77 & 4.25 & 0.66 & $45.35^{*}$ \\
\hline Oral communication skills & 4.60 & 0.48 & 4.62 & 0.59 & 4.61 & 0.54 & $46.88 *$ \\
\hline $\begin{array}{l}\text { Listening communication } \\
\text { skills }\end{array}$ & 3.11 & 0.32 & 4.54 & 0.63 & 3.84 & 0.87 & $260.95 *$ \\
\hline $\begin{array}{l}\text { Digital communication } \\
\text { skills }\end{array}$ & 4.55 & 0.46 & 4.07 & 0.77 & 4.31 & 0.68 & $33.28 *$ \\
\hline $\begin{array}{l}\text { Non-verbal communication } \\
\text { skills }\end{array}$ & 4.70 & 0.44 & 4.05 & 0.80 & 4.37 & 0.72 & $68.34 *$ \\
\hline \multicolumn{8}{|l|}{ Soft skills } \\
\hline \multicolumn{8}{|l|}{ Cronbach's Alpha $=0.922$} \\
\hline $\begin{array}{l}\text { Demonstrating emotional } \\
\text { self-control }\end{array}$ & 4.55 & 0.72 & 4.26 & 0.83 & 4.40 & 0.79 & $8.67 * *$ \\
\hline Resolving conflict & 4.73 & 0.60 & 4.59 & 0.65 & 4.66 & 0.63 & $14.50 *$ \\
\hline Building relationships & 4.81 & 0.50 & 4.46 & 0.73 & 4.63 & 0.65 & $123.88^{*}$ \\
\hline Building trust & 4.73 & 0.59 & 4.56 & 0.65 & 4.64 & 0.62 & $25.30 *$ \\
\hline Demonstrating respect & 4.77 & 0.54 & 4.75 & 0.55 & 4.76 & 0.55 & $0.78 * * *$ \\
\hline Integrity & 4.48 & 0.67 & 4.42 & 0.72 & 4.45 & 0.69 & $2.04 * * *$ \\
\hline Kindness & 4.82 & 0.48 & 4.72 & 0.56 & 4.77 & 0.52 & $22.87 *$ \\
\hline Responsibility & 4.82 & 0.52 & 4.79 & 0.51 & 4.81 & 0.51 & $1.88 * * *$ \\
\hline $\begin{array}{l}\text { Ability in social } \\
\text { relationships }\end{array}$ & 4.64 & 0.62 & 4.31 & 0.77 & 4.47 & 0.72 & $14.91 *$ \\
\hline Building optimism & 4.62 & 0.65 & 4.40 & 0.76 & 4.51 & 0.72 & $14.56^{*}$ \\
\hline Professionalism & 4.79 & 0.50 & 4.76 & 0.52 & 4.78 & 0.51 & $2.11 * * *$ \\
\hline Flexibility & 4.55 & 0.661 & 4.37 & 0.67 & 4.46 & 0.67 & $0.38 * * *$ \\
\hline Building team bonds & 4.63 & 0.646 & 4.25 & 0.81 & 4.44 & 0.75 & $28.46^{*}$ \\
\hline Work ethics & 4.67 & 0.618 & 4.54 & 0.71 & 4.60 & 0.67 & $13.17 *$ \\
\hline
\end{tabular}

Significance level: $* \mathrm{p}<0.001 ; * * \mathrm{p}<0.05 ; * * * \mathrm{p}>0.05$

Results show statistically significant differences between the importance of all five items of Communication skills. Moreover, results reveal that the future tourism professionals' and tourists' perceptions of importance do not differ significantly for Demonstrating respect, Integrity, and Responsibility in the Soft skills factor, whereas there is a 
ToSEE - Tourism in Southern and Eastern Europe, Vol. 6, pp. 167-185, 2021. A. Čuić Tanković, J. Kapeš, V. Kraljić: IMPORTANCE OF SOFT SKILLS AND COMMUNICATION ...

significant difference for Resolving conflict, Building relationships, Building trust, Kindness, Ability in social relationships, Building optimism, and Work ethics.

Figure 1 and Figure 2 present boxplots displaying the distribution of data for the factors of Communication skills and Soft skills based on the two samples. The Communication skills factor presents outliers in the distribution, with the minimum starting at 3 for the tourist sample, and at 3.50 for the future tourism professional sample. The differences between the data can be seen in the distribution of the first and third quartile, where the results pertaining to the future tourism professional sample are tightly grouped, but the median is the similar. The tourist sample has a higher maximum.

Figure 1: Differences in Communication skills

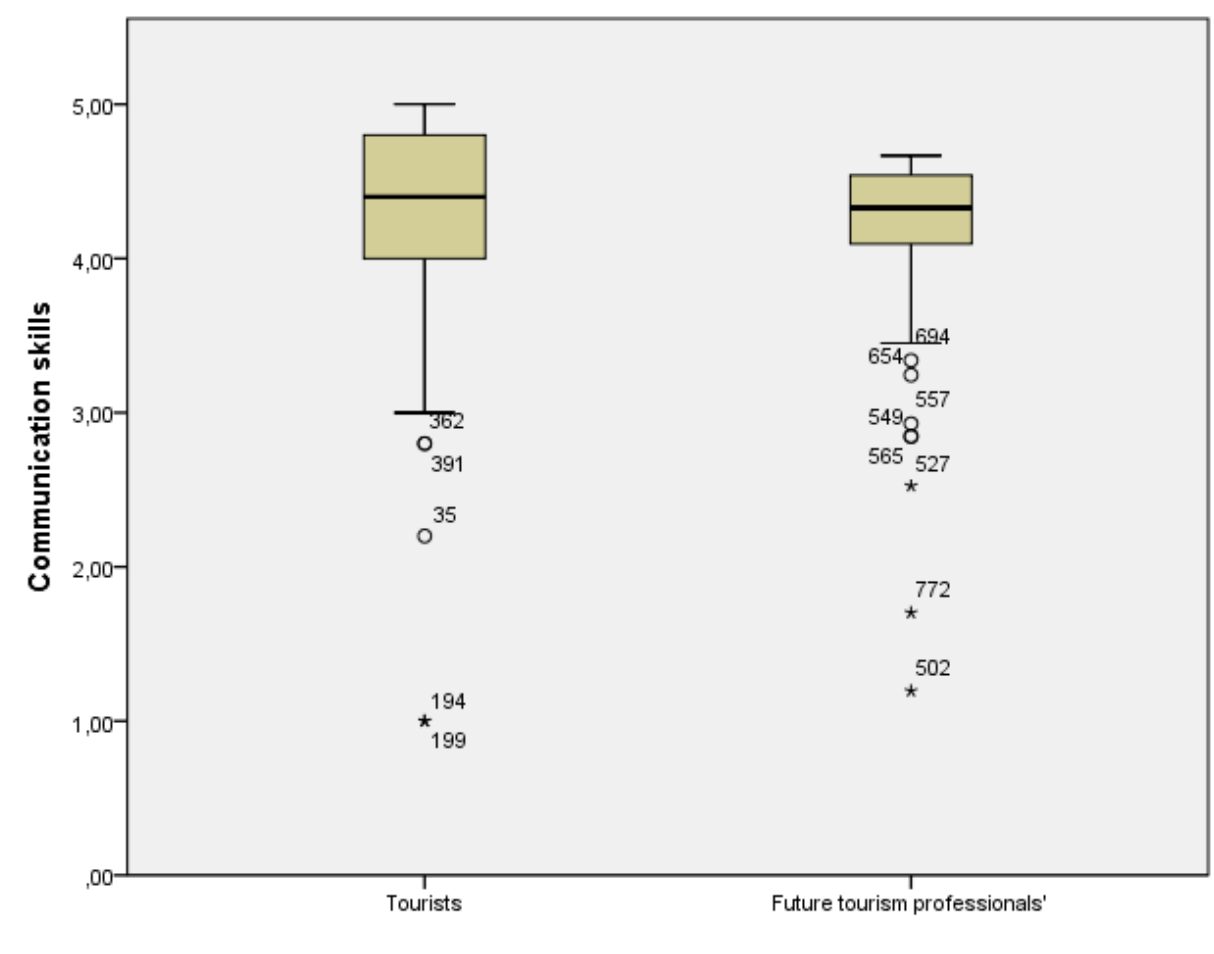




\section{Figure 2: Difference in Soft skills}

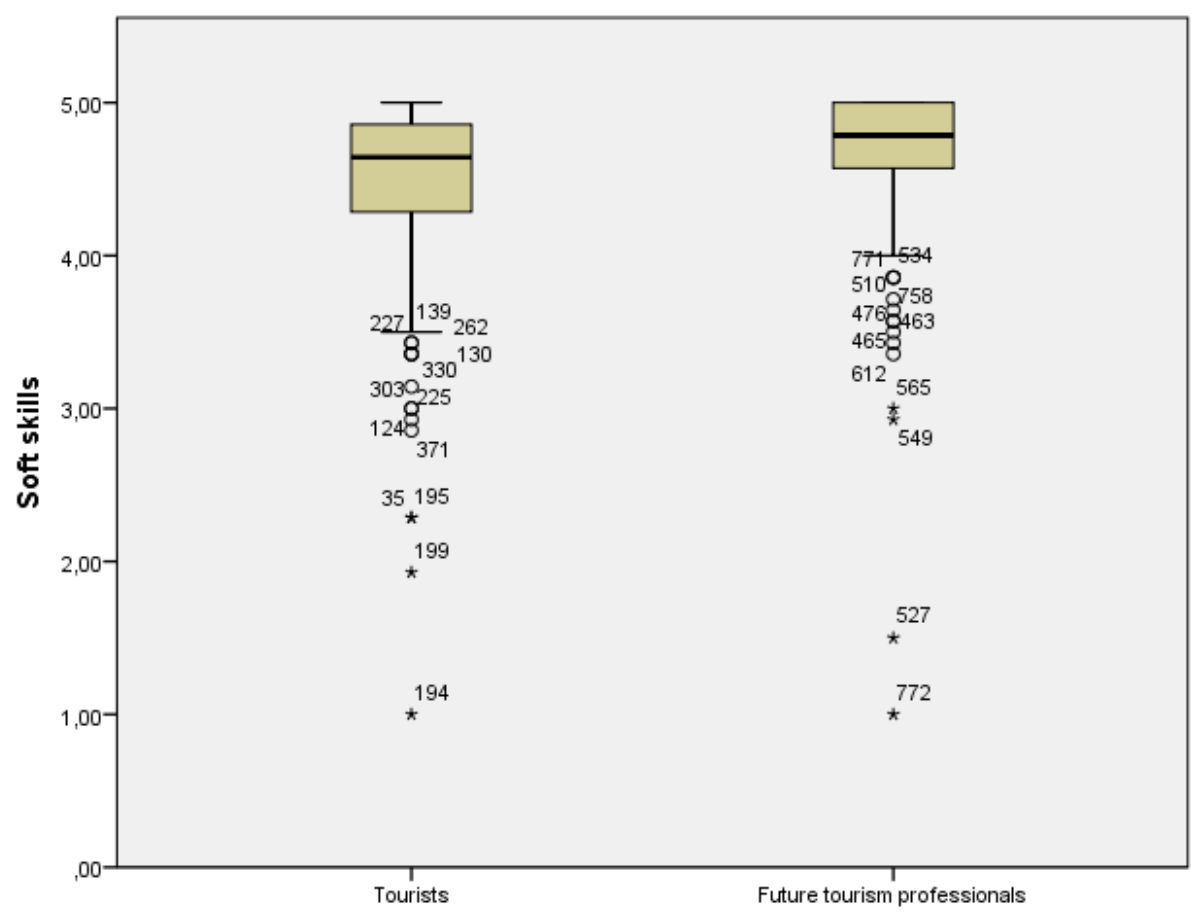

Figure 2 explains the distribution of the data for Soft skills and the differences between the two samples. The maximum is the same as the third quartile for the future tourism professional sample, which has a higher minimum than the tourist sample. The distribution of the data for the future tourism professional sample is tighter than for the tourist sample.

Both Figures 1 and 2 prove that the data are not symmetrical and are skewed, so a nonparametric test was used for the further examination.

By applying the Independent-Samples Mann-Whitney U Test, a statistically significant difference between the groups was noted for Soft skills $(\mathrm{p}<0.001)$, thereby confirming the first hypothesis (H1). On the other hand, no significant difference was noted for Communication skills ( $\mathrm{p}=0.057)$, thus rejecting the second hypothesis $(\mathrm{H} 2)$.

\section{CONCLUSION}

This paper aims to contribute to the discussion regarding the growing importance of soft skills and communication skills. The research results suggest that both tourists and future tourism professionals are aware of the importance of soft skills and communication skills. 
ToSEE - Tourism in Southern and Eastern Europe, Vol. 6, pp. 167-185, 2021.

A. Čuić Tanković, J. Kapeš, V. Kraljić: IMPORTANCE OF SOFT SKILLS AND COMMUNICATION ...

High average scores indicate that all soft skills are considered highly important by both groups. Tourist scores show that the highest importance is given to Responsibility, Professionalism, Demonstrating respect, and Kindness. Future tourism professionals rated the skills similarly, giving the highest scores to Kindness, Responsibility, Building relationships, and Demonstrating respect. Similar to Raybould and Wilkins's (2006) results, although a small variation was found in the importance ranking and the differences for three items did not prove significant, the difference in perception for the Soft skills factor is statistically significant. The results support previous findings on the importance of soft skills (Robles 2012; Conrad and Newberry 2012; Jiang and Alexakis 2017). The future tourism employees, however, show greater awareness of the importance of soft skills in this study than they do in some previous studies, perhaps due to the recently increased focus on these type of the skills in university curriculum (Ritter et al. 2018; Yan et al. 2019).

When observing average scores for communication skills, results indicate their high relevance for both groups. Non-verbal communication skills appear to be the most important for future tourism employees. Furthermore, oral communication skills were ranked highly by both groups, which is consistent with previous research (Clokie and Fourie 2016; Coffelt, Baker, and Corey 2016; Jackson 2014). According to Jiang and Alexakis (2017), strong oral communication skills will remain crucial in the hospitality industry as those are the skills that assure guest satisfaction. A notable discrepancy is seen in listening skills that are highly rated by tourists but received the lowest score from future tourism employees. These findings support some recent studies where authors state that new generations have a serious lack of listening skills (Bejtkovský 2016; Schroth 2019). Thus, the future tourism employees' perception appears to be conflicting with tourist expectations as well as with demands of the tourism workplace where listening is highly valued (Keyton et al. 2013; Clokie and Fourie 2016). When observed independently, the perception for all five communication skills significantly differs between tourists and future tourism professionals. However, the difference for the Communication skills factor did not prove to be statistically significant.

This research broadens the literature on soft skills and communication skills in the context of tourism. Besides the conceptualization of observed skills, it upgrades the existing knowledge on future tourism professionals' perception and industry requirements, by adding the tourists' point of view that has been overlooked by researchers so far. Although discrepancies appear to be small, a comparison of the perception of future tourism employees as service providers, and tourists as service users, provides tourism educators with clear guidelines as to the skills they should focus on. From this follows the study's practical contribution. As several scholars have stated (Jackson 2014; Raybould and Wilkins 2006), collaboration is needed between academia and industry to successfully prepare students in universities for the contemporary workplace. It is a shared responsibility which requires educating students prior to sending them to the workplace (Hartman and McCambridge 2011). Several researchers have emphasized the need to embed the soft skills and communication skills training in schools curriculum (Singh and Jaykumar 2019; Succi and Canovi 2019). Formal education is more focused on building knowledge than skills although interpersonal skills and communication are highly needed in the tourism workplace (Wesley, Jacskon, and Lee 2017; Jiang and Alexakis 2017; Lolli 2013). Therefore, the research suggests 
ToSEE - Tourism in Southern and Eastern Europe, Vol. 6, pp. 167-185, 2021.

A. Čuić Tanković, J. Kapeš, V. Kraljić: IMPORTANCE OF SOFT SKILLS AND COMMUNICATION ...

that greater attention should be focused on the development of soft skills and communication skills, particularly listening and oral communication skills, as well as people skills such as professionalism, responsibility, and demonstrating respect.

This study has some limitations which suggest directions for future research. Firstly, it should be noted that this research examines only the importance of skills from both sides, while the actual or perceived performance remains unknown. Therefore, in future research Importance-Performance Analysis could be applied to gain more information and draw more detailed recommendations for tourism educators. Furthermore, as stated by Raybould and Wilkins (2006), the needs and expectations for employee skills change over time, so a longitudinal research should be employed. Another limitation is the scope of the questionnaire. All the examined skills include a range of competences that could be measured. Therefore, for future research it is suggested to expand the measurement instrument for both communication skills and soft skills to gain a more detailed understanding. Finally, future studies could also focus on examining the perceived importance of soft skills and communications skills on a sample of tourism workers currently employed in the industry.

\section{ACKNOWLEDGEMENTS}

This paper was funded under the project line ZIP UNIRI of the University of Rijeka, for the project ZIP-UNIRI-116-4-19.

\section{REFERENCES}

Alhelalat, J.A., Habiballah, M.A., and Twaissi, N.M. (2017), "The impact of personal and functional aspects of restaurant employee service behaviour on customer satisfaction", International Journal of Hospitality Management, Vol. 66, pp. 46-53. https://doi.org/10.1016/j.ijhm.2017.07.001

Alshatnawi, E.A.R. (2013)., "Assessing communication skills among Jordanian tour guides: German tourists perceptions", Journal of Management Research, Vol. 6, No. 1, pp. 1-11. https://doi.org/10.5296/jmr.v6i1.4361

Baker, M., Murrmann, S.K., and Green, C. (2013), "Dining in the city: server behaviors, time preferences, and the effect of urbanization in restaurants", Journal of Foodservice Business Research, Vol. 16, No. 2, pp. 113-138. https://doi.org/10.1080/15378020.2013.761042

Balcar, J. (2016), "Is it better to invest in hard or soft skills?", The Economic and Labour Relations Review. Vol. 27, No. 4. pp. 453-470. https://doi.org/10.1177/1035304616674613

Barnes, S. J., Mattsson, J., Sørensen, F., and Jensen, J. F. (2020), "Measuring employee-tourist encounter experience value: A big data analytics approach", Expert Systems With Applications, Vol. 154, pp. 1-10. https://doi.org/10.1016/j.eswa.2020.113450

Baum, T., Kralj, A., Robinson, R. N., and Solnet, D. J., (2016), "Tourism workforce research: A review, taxonomy and agenda", Annals of Tourism Research, Vol. 60. pp. 1-22. https://doi.org/10.1016/j.annals.2016.04.003

Bharwani, S., and Jauhari, V. (2013), "An exploratory study of competencies required to co-create memorable customer experiences in the hospitality industry", International Journal of Contemporary Hospitality Management, Vol. 25, No. 6, pp. 823-843. https://doi.org/10.1108/IJCHM-05-20120065

Bejtkovský, J. (2016), “The employees of baby boomers generation, generation X, generation Y and generation $\mathrm{Z}$ in selected Czech corporations as conceivers of development and competitiveness in their corporation", Journal of Competitiveness, Vol. 8, No. 4, pp. 105-123. https://doi.org/10.7441/joc.2016.04.07

Bencsik, A., Horváth-Csikós, G., and Juhász, T. (2016), "Y and Z Generations at Workplaces ”, Journal of Competitiveness, Vol. 8, No. 3, pp. 90-106. doi:10.7441/joc.2016.03.06 
ToSEE - Tourism in Southern and Eastern Europe, Vol. 6, pp. 167-185, 2021.

A. Čuić Tanković, J. Kapeš, V. Kraljić: IMPORTANCE OF SOFT SKILLS AND COMMUNICATION ...

Brownell, J. (2009), "Fostering service excellence through listening: What hospitality managers need to know", Cornell Hospitality Report, Vol. 9, No. 6, pp. 6-18. https://hdl.handle.net/1813/71020

Brownell, J. (2016), Listening: Attitudes, Principles and Skills, Routlegde, New York.

Burns, M.P. (1997), "Hard-skills, soft-skills: undervaluing hospitality's 'service with a smile'", Progress in Tourism and Hospitality Research. Vol. 3, No. 3, pp. 239-248.

Carlisle, S., Ivanov, S., and Dijkmans, C. (2021), "The digital skills divide: evidence from the European tourism industry" Journal of Tourism Futures. Vol. ahead-of-print, No. ahead-of-print.

Cheung, C., Law, R. and He, K. (2010), "Essential Hotel Managerial Competencies for Graduate Students", Journal of Hospitality \& Tourism Education, Vol. 22, No. 4, pp. 25-32. https://doi.org/10.1080/10963758.2010.10696989

Ciappei, C. and Cinque, M. (2014), Soft skills per il governo dell'agire, Franco Angeli, Milano.

Clokie, T. L. and Fourie, E. (2016), "Graduate employability and communication competence: Are undergraduates taught relevant skills?", Business and Professional Communication Quarterly, Vol 79, No. 4, pp. 442-463. https://doi.org/10.1177/2329490616657635

Coffelt, T.A., Baker, M.J., and Corey, R.C. (2016), "Business communication practices from employers' perspectives” Business and Professional Communication Quarterly, Vol. 79, No. 3, pp. 300-316. https://doi.org/10.1177/2329490616644014

Coffelt, T.A., Grauman, D., and Smith, F.L. (2019), “Employers' perspectives on workplace communication skills: The meaning of communication skills", Business and Professional Communication Quarterly, Vol. 82, No. 4, pp. 418-439. https://doi.org/10.1177/2329490619851119

Conrad, D., Newberry, R. (2012), "Identification and Instruction of Important Business Communication Skills for Graduate Business Education", Journal of Education for Business, Vol. 87, No. 2, pp. 112-120. https://doi.org/10.1080/08832323.2011.576280

Dogara, G., Bin Saud, M.S., Bin Kamin, Y., and Bin Nordin, M.S. (2020), "Project-Based Learning Conceptual Framework for Integrating Soft Skills Among Students of Technical Colleges", IEEE Access, Vol. 8, pp. 83718-83727. doi: 10.1109/ACCESS.2020.2992092.

Eshet-Alkalai, Y. (2004), "Digital literacy: A conceptual framework for survival skills in the digital era", Journal of Educational Multimedia and Hypermedia, Vol. 13, No. 1, pp. 93-160.

Ferrari, A. (2014), "DIGCOMP: A Framework for Developing and Understanding Digital Competence in Europe", Joint research Center of European Comission.

Gaidhani, S., Arora, L., and Sharma, B.K. (2019), "Understanding the attitude of generation Z towards workplace", International Journal of Management, Technology and Engineering, Vol. 9, No. 1, pp. 2804-2812.

Gray, E.F. and Murray, N. (2011), “"A distinguishing factor": Oral communication skills in new accountancy graduates", Accounting Education: An International Journal, Vol. 20, No. 3, pp. 275-294. https://doi.org/10.1080/09639284.2011.560763

Goh, E. and Lee, C. (2018), "A workforce to be reckoned with: The emerging pivotal Generation Z hospitality workforce”, International Journal of Hospitality Management, Vol. 73, pp. 20-28 https://doi.org/10.1016/j.ijhm.2018.01.016

Gruzdev, M.V., Kuznetsova, I.V., Tarkhanova, I.Y., and Kazakova, E.I. (2018), "University Graduates' Soft Skills: The Employers' Opinion”, European Journal of Contemporary Education, Vol. 7, No. 4, pp. 690-698.

Hartman, J.L. and McCambridge, J. (2011), “Optimizing millennials' communication styles", Business Communication Quarterly, Vol. 74, No. 1, pp. 22-44. https://doi.org/10.1177/1080569910395564

Hendarman, A.F. and Tjakraatmadja, J.H. (2012), "Relationship among soft skills, hard skills, and innovativeness of knowledge workers in the knowledge economy era", Procedia-Social and Behavioral Sciences, Vol. 52, pp. 35-44. https://doi.org/10.1016/j.sbspro.2012.09.439

Hurrell, S.A. (2016), "Rethinking the soft skills deficit blame game: Employers, skills withdrawal and the reporting of soft skills gaps", Human Relations, Vol. 69, No. 3, pp. 605-628. https://doi.org/10.1177/0018726715591636

Islam, M.S. and Kirillova, K. (2020), "Non-verbal communication in hospitality: At the intersection of religion and gender" International Journal of Hospitality Management, Vol. 84, pp. 1-9. https://doi.org/10.1016/j.ijhm.2019.102326

Jackson, D. (2014), "Business graduate performance in oral communication skills and strategies for improvement", The International Journal of Management Education, Vol. 12, No. 1, pp. 22-34. https://doi.org/10.1016/j.ijme.2013.08.001

Jiang, L. and Alexakis, G. (2017), "Comparing students' and managers' perceptions of essential entry-level management competencies in the hospitality industry: An empirical study", Journal of Hospitality, Leisure, Sport \& Tourism Education, Vol. 20, pp. 32-46. https://doi.org/10.1016/j.jhlste.2017.01.001 
ToSEE - Tourism in Southern and Eastern Europe, Vol. 6, pp. 167-185, 2021.

A. Čuić Tanković, J. Kapeš, V. Kraljić: IMPORTANCE OF SOFT SKILLS AND COMMUNICATION ...

Jones, C.G. (2011), "Written and computer-mediated accounting commnunication skills: An employer perspective", Business Communication Quarterly, Vol. 74, No. 3, 241-271. https://doi.org/10.1177/1080569911413808

Keyton, J., Caputo, J.M., Ford, E.A., Fu, R., Leibowitz, S.A., Liu, T., Polasik, S.S., Ghosh, P., and Wu, C. (2013), "Investigating verbal workplace communication bevaiors", Journal of Business Communication, Vol. 50, No. 2, pp. 152-169. https://doi.org/10.1177/0021943612474990

Kleckner, M.J. and Marshall, C.R. (2014), "Critical communication skills: Developing course competencies to meet workforce needs", The Journal of Research in Business Education, Vol. 56, No. 2, pp. 59-81.

Knapp, M.L., Hall, J.A., and Horgan, T.G. (2014), Nonverbal communication in human interaction (8th Ed.) Cengage Learning, Boston.

Laker, D.R. and Powell, J.L. (2011), "The differences between hard and soft skills and their relative impact on training transfer", Human Resource Development Quarterly, Vol. 22, No. 1, pp. 111-122. https://doi.org/10.1002/hrdq.20063

Lim, Y.M., Lee, T.H., Yap, C.S., and Ling, C.C. (2016), "Employability skills, personal qualities, and early employment problems of entry-level auditors: Perspectives from employers, lecturers, auditors, and students", Journal of Education for Business, Vol. 91, No. 4, pp. 185-192. https://doi.org/10.1080/08832323.2016.1153998

Limbu, Y.B., Jayachandran, C., Babin, B.J., and Peterson, R.T. (2016), "Empathy, nonverbal immediacy, and salesperson performance: the mediating role of adaptive selling behavior", Journal of Business \& Industrial Marketing, Vol. 31, No.5, pp. 654-667. https://doi.org/10.1108/JBIM-03-2015-0048

Lolli, J. (2013), "Perceptions of the importance and preparedness of interpersonal communication skills of the entry-level hospitality leader: Implications for hospitality educators", Journal of Teaching in Travel \& Tourism, Vol. 13, No. 4, pp. 354-373. https://doi.org/10.1080/15313220.2013.839302

Loreto, M.M. (2020), "Teaching and Learning Interpersonal Communication: Perspectives of Hospitality Students”, Dusit Thani College Journal, Vol. 14, No. 2, pp. 555-574.

MacDermott, C. and Ortiz, L. (2017), "Beyond the business communication course: A historical perspective of the where, why, and how of soft skills development and job readiness for business graduates", IUP Journal of Soft Skills, Vol. 11, No. 2, pp. 7-24.

Mandal, F.B. (2014), "Nonverbal communication in humans" Journal of Human Behavior in the Social Environment, Vol. 24, No. 4, pp. 417-421. https://doi.org/10.1080/10911359.2013.831288

Morgan, G.J. (1997), "Communication skills required by accounting graduates: practicioner and academic perceptions", Accounting Education, Vol. 6, No. 2, pp. 93-107. https://doi.org/10.1080/096392897331514

Mustelier-Puig, L.C., Anjum, A., and Ming, X. (2019), "Service encounter communication, altruistic value, and customer satisfaction: a study of overseas tourists buying transportation services in Shanghai", Journal of China Tourism Research, Vol. 15, No. 2, pp. 149-171. https://doi.org/10.1080/19388160.2018.1545717

Muzio, E. and Fisher, D. (2009), "Soft Skill Quantification (SSQ): Human Performance vs. Metric", Cost Engineering, Vol. 51, No. 3, pp. 26-31.

Nickson, D., Warhurst, C. and Dutton, E. (2005), "The importance of attitude and appearance in the service encounter in retail and hospitality", Managing Service Quality, Vol. 15, No. 2, pp. 195-208. https://doi.org/10.1108/09604520510585370

Nikolich, M.A. and Sparks, B.A. (1995), "The hospitality service encounter: the role of communication", Hospitality Research Journal, Vol. 19, No. 2, pp. 43-56. https://doi.org/10.1177/109634809501900205

Özdipçiner, N.S., Ceylan, S., \& Aktaş, E. (2017), “Comparison of Communication Skills of Tourism Students and Tourism Workers: Cases of Pamukkale” In Rugiero, C., Arslan, H. and Icbay, M.A., Reserch on Communication, International Association of Social Science Research, Biaylstok, pp. 43-52

Pandey, M., and Pandey, P. (2015), "Global employability of unemployed youth through soft skills" International Journal of Multidisciplinary Approach \& Studies, Vol. 2, No. 2, pp. 73-77.

Paranto, S.R. and Kelkar, M. (2000), "Employer satisfaction with job skills of business college graduates and its impact on hiring behavior", Journal of Marketing for Higher Education, Vol. 9, No. 3, pp. 7389. https://doi.org/10.1300/J050v09n03_06

Pečiuliauskienè, P. (2018), "The Structure of Interpersonal Communication Skills of the New Generation Senior School Students: The Case of Generations X and Z”, Pedagogika, Vol. 130, No. 2, pp. 116130. https://doi.org/10.15823/p.2018.26

Plant, K. and Slippers, J. (2015), "Improving the business communication skills of postgraduate internal audit students: A South African teaching innovation", Innovations in Education and Teaching International, Vol. 52, No. 3, pp. 310-321. https://doi.org/10.1080/14703297.2013.852480 
ToSEE - Tourism in Southern and Eastern Europe, Vol. 6, pp. 167-185, 2021.

A. Čuić Tanković, J. Kapeš, V. Kraljić: IMPORTANCE OF SOFT SKILLS AND COMMUNICATION ...

Ranade, S., Tamara, C., Castiblanco, E., and Serna, A. (2010), "Mapping competencies", Mechanical engineering, Vol. 132, No. 2, pp. 30-34. https://doi.org/10.1115/1.2010-Feb-3

Raybould, M. and Wilkins, H. (2006), "Generic Skills for Hospitality Management: A Comparative Study of Management Expectations and Student Perceptions", Journal of Hospitality and Tourism Management, Vol. 13, No. 2, pp. 177-188. https://doi.org/10.1375/jhtm.13.2.177

Ritter, B.A., Small, E.E., Mortimer, J.W., and Doll, J.L. (2018), "Designing management curriculum for workplace readiness: Developing students' soft skills", Journal of Management Education, Vol. 42, No. 1, pp. 80-103. https://doi.org/10.1177/1052562917703679

Robles, M.M. (2012), "Executive Perceptions of the Top 10 Soft Skills Needed in Today's Workplace", Business Communication Quarterly, Vol. 75, No. 4, pp. 453-465. https://doi.org/10.1177/1080569912460400

Schroth, H. (2019), “Are you ready for gen Z in the workplace?”, California Management Review, Vol. 61, No. 3, pp. 5-18. https://doi.org/10.1177/1080569912460400

Siddiq, F., Scherer, R., and Tondeur, J. (2015), “Teachers' Emphasis on Developing Students' Digital Information and Communication Skills (TEDDICS): A New Construct in 21st Century Education", Computers \& Education, No. 92-93, pp. 1-14. https://doi.org/10.1016/j.compedu.2015.10.006

Singh, A. and Jaykumar, P. (2019), "On the road to consensus: key soft skills required for youth employment in the service sector", Worldwide Hospitality and Tourism Themes, Vol. 11, No. 1, pp. 10-24. https://doi.org/10.1108/WHATT-10-2018-0066

Sisson, L.G. andAdams, A.R. (2013), "Essential hospitality management competencies: The importance of soft skills", Journal of Hospitality \& Tourism Education, Vol. 25, No. 3, pp. 131-145. https://doi.org/10.1080/10963758.2013.826975

Sitompul, S.S., Dalimunthe, F.I., and Muhammad, H.I.S. (2019, December), "The importance of the soft skill influence for the tourism community for the satisfaction of tourists at Parbaba beach in Samosir island" In 1st International Conference One Belt, One Road, One Tourism (ICOBOROT 2018). Atlantis Press, pp. 68-73.

Stevens, B. (2005), "What communication skills do employers want? Silicon Valley recruiters respond", Journal of Employment Counseling, Vol. 42, No. 1, pp. 2-9. https://doi.org/10.1002/j.21611920.2005.tb00893.x

Succi, C. and Canovi, M. (2019), "Soft skills to enhance graduate employability: Comparing students and employers perceptions", Studies in higher education, pp. 1-14.

Suh, E., West, J.J. and Shin, J. (2012), "Important competency requirements for managers in the hospitality industry", Journal of Hospitality, Leisure, Sport \& Tourism Education, Vol. 11, pp. 101-112. https://doi.org/10.1016/j.jhlste.2012.02.005

Summak, M.E. (2014). "A Study On The Communication And Emphatic Skills Of The Students Having Education On Tourism Sector" Journal of Institute of Social Science, Vol. 31, pp. 131-137.

Tesone, D.V. and Ricci, P. (2005), "Job Competency Expectations for Hospitality and Tourism Employees: Perceptions of Educational Preparation", Journal of Human Resources in Hospitality \& Tourism, Vol. 4, No. 2, pp. 53-62. https://doi.org/10.1300/J171v04n02_03

Testa, M.R. and Sipe, L. (2012), "Service-leadership competencies for hospitality and tourism management", International Journal of Hospitality Management, Vol. 31, pp. 648-658 https://doi.org/10.1016/j.ijhm.2011.08.009

Turner, A. (2015), “Generation Z: Technology and social interest”, The Journal of Individual Psychology, Vol. 71, No. 2, pp. 103-113. doi: 10.1353/jip.2015.0021

Ulinski, M. and O'callaghan, S. (2002), “A comparison of MBA students' and employers' perceptions of the value of oral communication skills for employment", Journal of Education for Business, Vol. 77, No. 4, pp. 193-197. https://doi.org/10.1080/08832320209599070

Wall, E.A. and Berry, L.L. (2007), "The combined effects of the physical environment and employee behavior on customer perception of restaurant service quality", Cornell Hotel and Restaurant Administration Quarterly, Vol. 48, No. 1, pp. 59-69. https://doi.org/10.1177/0010880406297246

Wang, J., Ayres, H., and Huyton, J. (2009), "Job ready graduates: A tourism industry perspective", Journal of Hospitality and Tourism Management, Vol. 16, No. 1, pp. 62-72. https://doi.org/10.1375/jhtm.16.1.62

Wang, Y. and Tsai, C. (2014), "Employability of Hospitality Graduates: Student and Industry Perspectives", Journal of Hospitality \& Tourism Education, Vol. 26, pp. 125-135. https://doi.org/10.1080/10963758.2014.935221

Weber, M.R., Crawford, A., Lee, J., and Dennison, D. (2013), “An exploratory analysis of soft skill competencies needed for the hospitality industry", Journal of Human Resources in Hospitality \& Tourism, Vol. 12, No. 4, pp. 313-332. https://doi.org/10.1080/15332845.2013.790245 
ToSEE - Tourism in Southern and Eastern Europe, Vol. 6, pp. 167-185, 2021.

A. Čuić Tanković, J. Kapeš, V. Kraljić: IMPORTANCE OF SOFT SKILLS AND COMMUNICATION ...

Weber, M.R., Finley, D.A., Crawford, A., and Rivera Jr, D. (2009), “An exploratory study identifying soft skill competencies in entry-level managers", Tourism and Hospitality Research, Vol. 9, No. 4, pp. 353361. https://doi.org/10.1057/thr.2009.22

Weber, M.R., Lee, J.J. and Crawford, A. (2019), "A suggested best practices for enhancing performance of soft skills with entry-level hospitality managers", Anatolia: An International Journal of Tourism and Hospitality Research, Vol. 31, No. 1, pp. 76-87. https://doi.org/10.1080/13032917.2019.1703770

Wesley, S.C., Jackson, V.P. and Lee, M. (2017), "The perceived importance of core soft skills between retailing and tourism management students, faculty and businesses" Employee Relations, Vol. 39, No. 1, pp. 79-99. https://doi.org/10.1108/ER-03-2016-0051

Wu, Y.C., Tsai, C.S., Hsiung, H.W., and Chen, K.Y. (2015), "Linkage between frontline employee service competence scale and customer perceptions of service quality", Journal of Services Marketing, Vol 29, No. 3, pp.224-234. https://doi.org/10.1108/JSM-02-2014-0058

Yan, L., Yinghong, Y., Lui, S.M., Whiteside, M., and Tsey, K. (2019), "Teaching "soft skills" to university students in China: the feasibility of an Australian approach", Educational Studies, Vol. 45, No. 2 , pp. 242-258. https://doi.org/10.1080/03055698.2018.1446328

Youssef, F. (2017), "The Role of Faculties of Tourism and Hotel Management in Developing the Etiquette and Communication Skills for Students within the Educational Community", International Journal of Heritage, Tourism and Hospitality, Vol. 11, No. 3, pp. 87-102. doi: 10.21608/IJHTH.2017.30223

Zehrer, A. and Mössenlechner, C. (2009), "Key competencies of tourism graduates: The employers' point of view", Journal of Teaching in Travel \& Tourism, Vol. 9, No. 3-4, pp. 266-287. https://doi.org/10.1080/15313220903445215

Ana Čuić Tanković, PhD, Assistant Professor

University of Rijeka, Faculty of Tourism and Hospitality Management Department of Marketing

Primorska 46, B.O. 97, 521410 Opatija, Croatia

+38551294759

anact@fthm.hr

Jelena Kapeš, MSc, Teaching Assistant

University of Rijeka, Faculty of Tourism and Hospitality Management

Department of Marketing

Primorska 46, B.O. 97, 521410 Opatija, Croatia

+38551294759

jkapes@fthm.hr

Valentina Kraljić, MSc, Graduated student

University or Rijeka, Faculty of Tourism and Hospitality Management

Primorska 46, B.O. 97, 521410 Opatija, Croatia

kraljicv62@gmail.com 